\title{
Strategi Promosi Perekrutan Siswa Di SMK Bisnis Dan Teknologi Terhadap Minat Siswa Untuk Mendaftar
}

\author{
Tjipto Djuhartono' ${ }^{1}$ Khoirul Umam²; Ai Annisa Utami ${ }^{3}$ \\ Pendidikan Ekonomi Universitas Indraprasta PGRI, Jakarta ${ }^{1,2,3}$
}

\begin{abstract}
This research concerns students' interest in deciding to enroll in Business and Technology Vocational Schools in terms of factors that influence students from information obtained through promotional media used by Vocational Business and Technology namely Banners, Brochures, Presentations, Friend Recommendations, Parent Choices, Own Choices, Teacher Recommendations and Others. The purpose of this research is to determine what strategies must be done by the Vocational Business and Technology through the promotional media used. The results of the 60 respondents showed that from eight sources of information about the Business and Technology Vocational Schools obtained by these students, the Brochure ranked first, followed by Parent Choices and then Friend Recommendations. The research method used is a survey using a questionnaire. The data obtained is then analyzed and presented in the form of tabulations.

Keywords: Promotion strategy, Vacational High School, Business School
\end{abstract}

\section{Pendahuluan}

Persaingan antar sekolah yang terjadi sekarang ini begitu kompetitif. Sebagai institusi pendidikan yang merupakan penyedia jasa pendidikan berusaha untuk memikirkan bagaimana cara yang tepat untuk meningkatkan kepuasan serta memenuhi kebutuhan para pelanggan yaitu para siswa dengan meningkatkan mutu pendidikan disekolah. Mutu pendidikan adalah gambaran dan karakteristik menyeluruh jasa pelayanan pendidikan secara internal ataupun ekternal yang menunjukkan kemampuannya memuaskan kebutuhan yang diharapkan. Dalam kurun waktu lima tahun terakhir, telah terjadi pertumbuhan jumlah unit sekolah baru di setiap propinsi. Setidaknya dari tiga propinsi yang dapat dirangkum oleh peneliti yaitu DKI Jakarta, Jawa Barat dan DI Yogyakarta, menunjukkan tren pertumbuhan. Jawa Barat merupakan propinsi dengan jumlah pertumbuhan terbesar dan memilik tren pertumbuhan signifikan selama 5 tahun terakhir yaitu pada tahun ajaran 2011/2012 sebesar 1.765 unit SMK, 2012/2013 sebesar 1.898 unit, tahun ajaran 2013/2014 sebesar 2.288, tahun ajaran 2014/2015 sebesar 2.442 unit dan 
tahun ajaran 2015/2016 sebesar 2.515 unit SMK. Sementara DKI Jakarta pad atahun ajaran 2011/2012 sebesar 598 unit, tahun ajaran 2012/2013 sebesar 615 unit, tahun ajaran 2013/2014 sebesar 592 unit, tahun ajaran 2014/2015 sebesar 600 unit, dan tahun ajaran 2015/2016 mengalami penurunan sebesar 586 unit. Jumlah pertumbuhan terendah berada pada propinsi DI Yogyakarta, yaitu pada tahun ajaran 2011/2012 sebesar 208 unit SMK, tahun ajaran 2012/2013 sebesar 225 unit SMK, tahun ajaran 2013/2014 turun sebesar 220, mengalami peningkatan kembali sebesar 222 unit SMK pada tahun ajaran 2014/2015 dan kembali turun sebesar 218 pada tahun ajaran 2015/2016, sebagaimana tercantum pada Gambar 1 di bawah ini.

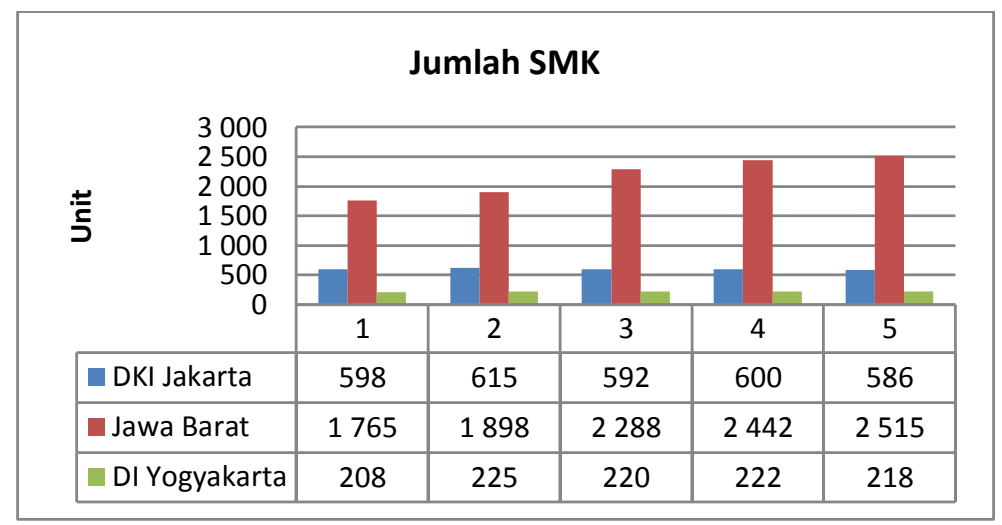

Sumber: BPS (data diolah)

Gambar 1. Jumlah SMK di bawah Kementerian Pendidikan dan Kebudayaan Menurut Propinsi tahun ajaran 2011/2012 s/d 2015/2016

Di sisi lain, pendidikan adalah salah satu bagian yang fundamental dalam meningkatkankualitas manusia. Pendidikan juga merupakan komponen variabel dalam menghitungIndeks Pembangunan Manusia (IPM). Pendidikan nasional harus mampu menjaminpemerataan kesempatan pendidikan, peningkatan mutu serta relevansi dan efisiensimanajemen pendidikan untuk menghadapi tantangan sesuai dengan tuntutan perubahan di era globalisasi dan pasar bebas. Arah pendidikan nasional menitikberatkan pada peningkatan mutu, otonomi dan peningkatan daya saing bangsa. Daya saing dapat diartikan sebagai kemampuan penyelenggaraan pendidikan yang sanggup berkompetisi dalam hal kualitas dengan bangsa-bangsa lain.

Deskripsi pendidikan itu sendiri telah tercantum di dalam Undang-Undang 
Republik Indonesia Nomor 20 Tahun 2003 tentang Sistem Pendidikan Nasional di Bab 1 pasal 1 Tentang Ketentuan Umum yang menyebutkan bahwa, pendidikan adalah usaha sadardan terencana untuk mewujudkan suasana belajar dan proses pembelajaran agar peserta didik secara aktif mengembangkan potensi dirinya untuk memiliki kekuatan spiritual keagamaan, pengendalian diri, kepribadian, kecerdasan, akhlak mulia, serta keterampilan yang diperlukan dirinya, masyarakat, bangsa dan negara. Artinya, untuk menciptakan manusia yang berkualitas, maka dibutuhkan upaya dan proses tersistematis yang mampu mengembangkan potensi dari siswa sebagai peserta didik, yaitu kompetensi. Antara lain adalah kompetensi spiritual, pengendalian diri, personalitas, intelegensia, akhlak, spesialisasi, kecerdasan sosial dan paham bahwa dirinya adalah bagian dari bangsa dan negara.

Pengembangan potensi diri pada peserta didik sangat dibutuhkan untuk menghadapi globalisasi pendidikan. Kekuatan spiritual keagamaan, pengendalian diri, kepribadian, kecerdasan, akhlak mulia sangat diperlukan dalam mengantisipasi derasnya arus globalisasi di segala bidang. Ketrampilan peserta didik tidak hanya diperlukan bagi dirinya, namun sangat diperlukan bagi masyarakat, bangsa dan negara. Hal ini nampak sekali terutama dalam mengatasi berbagai masalah sosial, terutama masalah pengangguran.

Salah satu isu yang sangat menarik untuk dikaji sebagaimana termuat dalam Rencana Strategis Departemen Pendidikan Nasional tahun 2015-2019 (Hal. 62: butir b) adalah adanya upaya dari pemerintah untuk meningkatkan ketersediaan SMA/SMK/MA di kecamatan-kecamatan yang belum memiliki satuan pendidikan menengah melalui pembangunan USB, terutama penambahan RKB, dan pembangunan SMP/MTs-SMA/MA satu atap, serta ketersediaan SMK yang mendukung pembangunan bidang pertanian, maritim, pariwisata, industri manufaktur, dan ekonomi kreatif. Sementara d pada poin "k", disebutkan bahwa adanya upaya pemerintah untuk melakukan penguatan kecakapan akademik siswa SMK seperti matematika, pemecahan masalah dan bahasa untuk memenuhi kebutuhan industri yang mensyaratkan penguasaan keterampilan dasar.

Kebijakan di atas ternyata tidak sinkron dengan kondisi yang terjadi di lapangan. Khususnya SMK (Sekolah Menengah Kejuruan) sebagai salah satu 
lembaga pendidikan formalyang bertujuan untuk mempersiapkan siswa agar memiliki kompetensi yang diperlukan dan siap masa transisi menuju dunia kerja, ternyata belum benar-benar mampu mewujudkan target pencapaian dari kebijakan pemerintah tersebut. Jika melihat angka prosentase dari jumlah lulusan SMK yang bekerja terhadap angkatan kerja, menunjukkan bahwa mulai dari tahun 2010 hingga 2018, mengalami tren menurun. Tren tertinggi dicapai pada tahun 2014 sebesar $92,79 \%$, dan merosot tajam sebesar 90,18\% pada tahun 2016. Meskipun mengalami penaikan di tahun 2017 dan 2018 yaitu sebesar 90,73\% dan 91,08\%, namun masih belum bisa meyentuh angka tertinggi yangtelah dicapai di tahun 2014. Artinya, prestasi lulusan SMK untuk diterima pada dunia kerja terutama di dunia industri, melemah sebagaimana yang tercantum pada Tabel 1 di bawah ini.

Tabel 1.2. Prosentase Jumlah Lulusan Pendidikan Tertinggi yang Bekerja terhadap Angkatan Kerja

\begin{tabular}{|c|c|c|c|c|c|c|c|c|c|}
\hline \multirow{2}{*}{$\begin{array}{c}\text { Pendidikan Tertinggi yang } \\
\text { DITAMATKAN }\end{array}$} & \multicolumn{9}{|c|}{ \% Bekerja / AK } \\
\hline & 2010 & 2011 & 2012 & 2013 & 2014 & 2015 & 2016 & 2017 & 2018 \\
\hline Tidak/belum pernah sekolah & 98,98 & 98,20 & 97,88 & 98,03 & 97,47 & 97,54 & 97,85 & 97,79 & 98,87 \\
\hline Tidak/belum tamat SD & 97,08 & 97,01 & 96,68 & 96,98 & 96,48 & 96,78 & 96,56 & 96,94 & 97,46 \\
\hline SD & 95,37 & 96,11 & 95,86 & 95,93 & 96,05 & 95,98 & 96,38 & 96,02 & 97,09 \\
\hline SLTP & 92,45 & 92,13 & 92,14 & 91,79 & 92,56 & 92,86 & 94,24 & 94,64 & 94,82 \\
\hline SLTA Umum/SMU & 88,10 & 87,43 & 89,47 & 90,55 & 90,90 & 91,83 & 93,04 & 92,97 & 92,81 \\
\hline SLTA Kejuruan/SMK & 86,19 & 89,90 & 90,41 & 92,28 & 92,79 & 90,95 & 90,18 & 90,73 & 91,08 \\
\hline Akademi/Diploma & 84,29 & 87,76 & 92,43 & 94,28 & 94,13 & 92,51 & 92,78 & 93,65 & 92,08 \\
\hline Universitas & 85,76 & 89,77 & 92,98 & 94,98 & 95,69 & 94,66 & 93,78 & 95,02 & 93,69 \\
\hline
\end{tabular}

Beberapa penyebab dari terjadinya kondisi tersebut di atas antara lain masalah kompetensi lulusan SMK yang kebanyakan tidak memenuhi standar kebutuhan industri dan perusahaan. Hal ini terjadi karena penerapan kurikulum belajar yang tidak sinkron dengan kebutuhan dunia kerja secara riil sehingga mengakibatkan lulusan SMK tidak siap untuk masuk ke dunia kerja, terutama industri. Masalah kedua adalah kompetensi guru yang mengajar. Persoalan yang muncul adalah ketika guru yang mengajar mata pelajaran produktif tidak memiliki latar belakang pengetahuan dan pendidikan yang sesuai dengan mata pelajaran yang diajarkannya, atau bahkan tidak pernah terjun ke lapangan, sehingga tidak memiliki basic experince yang mapan untuk mempertajam materi pelajaran yang diajarkan 
kepada siswanya. Masalah ketiga adalah kemampuan sekolah dalam menyediakan sarana dan pra sarana belajar yang mendukung siswa untuk menerapkan ilmunya di lapangan seperti laboratorium, bengkel, dan sejenisnya. Tidak semua SMK mampu menyediakan infrastruktur pembelajaran tersebu dengan baik, sehingga mengakibatkan siswa sering kali tidak melakukan praktikum secara sempurna sebagai bagian dari penerapan teori yang diperolehnya di kelas.

Merujuk kepada ketentuan pemerintah di atas mengenai daya saing SMK terhadap dunia kerja dan industri, maka dibutuhkan strategi manajerial yang baik bagi SMK agar bisa menyesuaikan diri dan mampu mempertahankan jumlah penerimaan siswa dan lulusan yang berkualitas. Salah satu upaya yang dilakukan adalah melakukan promosi sebagaimana yang dilakukan oleh SMK Bisnis dan Teknologi. Dalam perjalanannya, SMK Bisnis dan Teknologi mengalami kondisi tidak hanya harus mempersiapkan lulusan yang berkompeten dan berkompetisi dalam dunia bisnis dan industri, namun juga berusaha untuk mempertahankan eksistensinya di tengah-tengah persaingan dengan SMA dan SMK lainnya yang juga memiliki kompetensi lebih baik. Salah satu tantangan yang dihadapi oleh SMK Bisnis dan Teknologi adalah menentukan strategi apa yang mampu meningkatkan minat siswa baru untuk mau mendaftar di SMK Bisnis dan Teknologi tersebut.

Sehingga berangkat dari persoalan di atas, maka peneliti mencoba untuk meneliti bentuk-bentuk strategi apa yang layak untuk digunakan oleh SMK Bisnis dan Teknologi dalam upaya meningkatkan minat siswa mendaftar dengan judul penelitian adalah Strategi Prommosi Perekrutan Siswa di SMK Bisnis dan Teknolgi Terhadap Minat Siswa Untuk Mendaftar.

Berdasarkan uraian dari latar belakang di atas, maka rumusan masalah yang akan diteliti adalah sebagai berikut:

1. Upaya apa yang harus dilakukan oleh SMK Bisnis dan Teknologi dalam meningkatkan kualitas jasa pendidikannya kepada siswa?

2. Strategi promosi apa yang harus dilakukan oleh SMK Bisnis dan Teknologi untuk dapat meningkatkan jumlah siswa 


\section{Tinjauan Pustaka}

\section{Pengertian Pelayanan}

Secara umum, pelayanan di definisikan lebih kepada kontekstual dari kata tersebut. Banyak artkel ilmiah yang menyebutkan kata service namun diterjemahkan ke dalam bahasa Indonesia, memiliki arti dan makna berbeda, antara lain layanan, jasa dan servis. Dalam bahasa Inggris sendiri, istilah service pun diterjemahkan berbeda. Oxford Advanced Learner's Dictionary (2000) setidaknya mendefinisikan kata service antara lain sebagai berikut:

1). Kondisi atau posisi menjadi pelayan atau pembantu

2). Penyerahan formal dokumen resmi kepada seseorang

3). Tindakan untuk memeukul bola dalam permainan olah raga tenis, tenis meja, bulu tangkis, bola volley

4). Melayani pelanggan di hotel, restoran dan toko

5). Bisnis yang pekerjaannya melakukan sesuatu bagi pelanggan tetapi tidak menghasilkan barang. Pekerjaan-pekerjaan seperti ini meliputi jasa finansial,perbankan dan asuransi

6). Keterampilan atau bantuan tertentu yang bisa ditawarkan seseorang

Keanekaragaman makna dalam hal pemakaian istilah service juga dijumpai dalam literatur manajemen.Dalam perspektif manajemen, kata service mengacu pada tiga lingkup definisi utama, yaitu: industri, output atau penawaran, dan proses (Johns, 1999; dalam Fandi 2011). Dalam konteks indutsri, istilah jasa (service) digunakan untuk menggambarkan berbaggai sub-sektor dalam kategori aktivitas ekonomi, seperti transportasi, finansial, perdagangan ritel, personal services, kesehatan, pendidikan dan layanan publik. Dalam lingkup penawaran, jasa dipandang sebagai produk intangible yang outputnya lebih berupa aktifitas ketimbang obyek fisik, meskipun dalam kenyataannya banyak pula jasa yang melibatkan produk fisik. Sebagai proses, jasa mencerminkan penyampaian jasa inti, interaksi personal, kinerja dalam arti luas serta pengalaman layanan.

Lovelock, Peterson dan Walker (2004) dalam Fandy dan Gregorius (2011: p. 14) menjelaskan bahwa service dipandang sebagai sebuah sistem dalam setiap bisnis jasa yang memiliki dua komponen, yaitu (1) operasi jasa (service operation) 
di mana input diproses dan elemen-elemen produk jasa diciptakan; dan (2) penyampaian jasa (service delivery) di mana elemen-elemen produk jasa tersebut dirakit, dirampungkan dan disampaikan kepada pelanggan.

\section{Manajemen Kepuasan Pelanggan}

Fandy Tjiptono (2011: p. 292) mendefinisikan kepuasan sebagai "upaya pemenuhan sesuatu" atau membuat sesuatu memadai. Oxford Advanced Learner's Dictionary (2000) dalam Tjiptono (2011:p 292) mendeskripsikan kepuasan sebagai "the good feeling when you have the achieved something or when something that you wanted to happen does happen; the act of fulfilling a need or desire; dan an acceptable way of dealing with complain, a debt, an injury, etc".

Staus dan Nehaus (1997) dalam Tjiptono membedakan tiga tipe kepuasan dan dua tipe ketidakpuasan berdasarkan kombinasi antara emosi-emosi spesifik terhadappenyedia jasa., ekspektasi menyangkut kapabilitas kinerja masa depan pemasok jasa, dan minat berperilaku untuk memilih lagi penyedia jasa bersangkutan. Tipe-tipe kepuasan dan ketidakpuasan tersebut adalah demanding satisfaction, stable satisfaction, resigned satisfaction, stable dissatisfaction, dan demanding dissatisfaction.

Demanding customer satisfaction. Tipe ini merupakan tipe kepuasan yang aktif. Relasi dengan penyedia jasa diwarnai dengan emosi positif, terutama optimisme dna kepercaaan. Berdasarkan pengalaman positif masa lalu, pelanggan dengan tipe kepuasan ini berharap bahwa penyedia jasa bakal mampu memuaskan ekspektasi mereka yang semakin meningkat di masa depan. Selain itu, mereka bersedia meneruskan relasi. Namun demikian, loyalitas tergantung pada kemampuan penyedia jasa dalam meningkatkan kinerjanya seiring dengan meningkatnya tuntutan pelanggan

Stable customer satisfaction. Pelanggan dalam tipe ini memiliki aspirasi pasif dan perilaku yang demanding.Emosi positifnya terhadpa penyedia jasa bercirikan steadiness dan trust dalam relasi yang terbina saat ini. mereka menginginkan segala sesuatunya tetap sama.

Resigned customer satisfaction. Pelanggan dalam tipe ini juga merasa puas. Namun, kepuasannya bukan disebabkan oleh ekspektasi, lebih didasarkan kepada 
kesan bahwa tidak realistis untuk berharap lebih. Perilaku konsumen tipe ini cenderung pasif. Mereka tidak bersedia melakukan berbagai upaya dalam rangka menuntut berbagai situasi.

Stable customer dissatisfaction. Pelanggan dalam tipe ini tidak puas terhadap kinerja penyedia jasa, namun mereka cenderung tidak melakukan apa-apa. Relasi mereka dengan penyedia jasa diwarnai emosi negatif dan asumsi bahwa ekspektasi mereka tidak bakal terpenuhi di masa datang. Mereka juga tidak melihat adanya peluang untuk perubahan atau perbaikan

Demanding customer dissatisfaction. Tipe ini bercirikan tingkat aspirasi aktif dan perilaku demanding. Pada tingkat emosi, ketidakpuasannya menimbulkan protes dan oposis. Hal ini meyiratkan bahwa mereka akan aktif dalam menuntut perbaikan. Padasaat bersamaan, mereka juga merasa tidak perlu untuk tetap loyal pada penyedia jasa. Berdasarkan pengalaman negatifnya, mereka tidak akan memilih penyedia jasa yang sama lagi di kemudian hari.

\section{Pengukuran Kepuasan Pelanggan}

Ada beberapa metode yang bisa digunakan oleh perusahaan untuk mengukur dan memantau pelanggannya dan pelanggan pesaing. Kotler et.al (2004) dalam Tjiptono (2011: 314) mengidentifikasikan empat metode yang mengukur kepuasan pelanggan: sistem keluhan dan saran, ghost shopping, lost customer analysis, dan survey kepuasan pelanggan.

\section{Sistem Keluhan Pelanggan}

Setiap organisasi yang berorientasi pada pelanggan perlu menyediakan kesempatan dan akses yang mudah dan nyaman bagi para pelanggannya guna menyampaikan saran, kritik, dan pendapat serta keluhan mereka. Media yang digunakan bisa berupa kotak saran yang ditempatkan di lokasi-lokasi strategis ( yang mudah dijangkau atau sering dilewati pelanggan), kartu komentar yang bisa diisi langsung maupun yang dikirmkan via pos, saluran telepon khusu bebas pulsa, websites, dan lain-lain. Informasi yang diperoleh melalui metode ini dapat memberikan ide-ide baru yang berharga kepada perusahaan. Sehingga memungkinkan bagi perusahaan untuk bergerak secara tanggap dan cepat untuk mengatasi masalah-masalah yang timbul. Berdasarkan karakteristiknya, metode ini bersifat pasif, karena perusahaan 
menunggu inisiatif pelanggan untuk menyampaikan keluhan atau penndapat. Sehingga sulit memperoleh gambaran lengkap mengenai kepuasan atau ketidakpuasan pelanggan melalui cdara ini semata

\section{Ghost Shopping}

Salah satu cara untuk memperoleh gambaran kepuasan pelanggan adalah dengan mempekerjakan beberapa orang untuk berperan atau berpura-pura sebagai pelanggan potensial produk perusahaan dan pesaing. Mereka diminta untuk berinteraksi dengan staf penyedia jasa dan menggunakan produk perusahaan. Berdasarkan pengalamannya tersebut, mereka kemudian diminta melaporkan temuan-temuannya berkenaan dengan kekuatan dan kelemahan produk perusahaan dan pesaing.

\section{Lost Customer Analysis}

Sedapat mungkin sebaiknya perusahaan menghubungi kembali para pelanggan yang telah berhenti membeli atau yang telah pindah pemsok agar dapat memahami mengapa hal itu terjadi dan supaya dapatt mengambil kebijakan perbaikan/penyempurnaan selanjutnya

\section{Survey Kepuasan Pelanggan}

Melalui survey, perusahaan akan memperoleh tanggapan dan balikan secara langsung dari pelanggan dan juga memberikan kesan positif bahwa perusahaan menaruh perhatian terhadap para pelanggannya.

\section{Promosi}

Menurut Kotler dalam Rangkuti (2010: p. 49), promosi mencakup semua alat-alat bauran pemasaran yang peran utamanya adalah lebih mengadakan komunikasi yang sifatnya membujuk. Kegiatan promosi menurut Rangkuti (2010), merupakan hal yang sangat penting dan harus dapat memperlihatkan dengan cara yang tepat sehingga innformasi yang disampaikan dapat diterima dan dimengerti oleh masyarakat yang diharapkan dapat menjadi konsumen bagi perusahaan. Rangkuti menjelaskan bahwa promosi adalah kegiatan penjualan dan pemasaran dalam ranggka menginformasikan dan mendorong permintaan terhadap produk, jasa, dan ide dari perusahaan dengan cara memengaruhi konsumen agar mau membeli produk dan jasa yang dihasilkan oleh perusahaan. Sehingga karakteristik 
promosi menurut Rangkuti (2010) adalah sebagai berikut:

a. Promosi adalah salah satu variabel marketing mix yang memiliki peranan penting bagi perusahaan dalam menyebarkan informasi kepada konsumen dan publik.

b. Promosi berusaha menarik perhatian konsumen melalui informasi yang diberikan kepada konsumen untuk memberitahukan adanya produk baru perusahaan

c. Promosi adalah kegiatan perusahaan yang menyebarluaskan arus informasi agar konsumen terus mengingatnya sehingga timbul keinginan konsumen untuk mencoba dan membeli produk perusahaan.

d. Promosi berusaha mengubah sikap atau perilaku konsumen terhadap produk atau jas perusahaan

e. Promosi merupakan kegiatan yang secara langsung daat dilihat dan dirasakan konsumen dan secara tidak langsung juga memaksa konsumen untuk membeli poduk atau jasa perusahaan.

\section{Pengaruh Komunikasi Terhadap Pembentukan Sikap}

Sikap terdiri dari tiga komponen utama yaitu kognitif, afektif dan komponen konatif. Komponen konginitif terdiri dari pengetahuan konsumen tentang produk, merk, dan pemasar. Pengetahuan ini didapat dari kepercayaan terhadap atribut objek dan manfaat yang ditawarkan dan didasari oleh pengalaman konsumen pribadi dan informasi yang dikumpulkan baik dari pemasar maupun dari konsumen lainnya.

Komponen afektif meliputi perasaan dan emosi konsumen terhadap objek yang diwujudkan dengan mengevaluasi objek secara keseluruhan objek yang bersangkutan. Evaluasi ini banyak dipengaruhi oleh kepercayaan yan telah terbentuk sebelumnya. Komponen konatif adalah niat konsumen untuk bertindak terhadap suatu objek, biasanya berupa kecenderungan untuk membeli suatu produk untuk memuaskan kebutuhannya.

Sementara sikap adalah hasil dari proses belajar. Artinya, sikap yag cenderung relevan dengan perilaku pembelian adalah hasil bentukan dari pengalaman menggunakan produk secara langsung, informasi dari mulut ke mulut (word of 
mouth), komunikasi di berbagai media, internet maupun direct marketing.

\section{Metode Penelitian}

\section{Desain Penelitian}

Penelitian ini menggunakan pendekatan kuantitatif deskriptif. Subjek dalam penelitian ini adalah siswa yang belajar di SMK Bisnis dan Teknologi.Data dalam penelitian ini dikumpulkan dengan menggunakan metode survey, yang digunakan untuk mengumpulkan data berupa sikap, tanggapan dan respon siswa dari pengalaman yang pernah dialaminya terhadap pelayanan, sarana dan pra sarana yang dimiliki oleh SMK Bisnis dan Teknologi. Pada penelitian ini pengumpulan data juga dilakukan dengan menggunakan kuesioner dimana yang digunakan dalam penelitian ini adalah kuesionerpenilaian siswa terhadap kinerja pelayanan secara umum baik ditinjau dari sisi pengajaran maupun infrastruktur yang disediakan.

\section{Lokasi Penelitian}

Lokasi penelitian dilakukan di SMK Bisnis dan Teknologi yang beralamat di Jalan Cikunir Raya No. 1, Jakamulya, Bekasi Selatan, Jaka Mulya, Bekasi Sel., Kota Bks, Jawa Barat 17146

\section{Populasi}

Populasi yang diperoleh adalah guru mata pelajaran di SMK Bisnis dan Teknologi sebesar 60 orang

\section{Teknik Pengumpulan Data}

Penelitian ini dengan wawancara, dengan menggunakan kuesioner terhadap responden.

\section{Instrumen Penelitian}

Instrumen penelitian yang digunakan adalah kuesioner yang digunakan oleh peneliti untuk mengumpulkan data dari dua variabel, yaitu variabel independen dan dependen.

\section{Hasil Dan Pembahasan}

\section{Hasil}

Dalam hasil penelitian ini disajikan data hasil penghitungan dari 60 siswa responden. Data tersebut kemudian disajikan ke dalam bentuk grafik dan tabel yang merupakan hasil penghitungan dari setiap item pertanyaan dan variabel yang 
dianalisa.Variabel penilaian yang dihitung adalah penilaian siswa terhadap bentuk promosi yang dilakukan oleh SMK Bisnis dna Teknologi dalam bentuk Iklan, Sales Promotion, Word of Mouth, Public Relation, dan Event Marketing dengan indikator YA dan TIDAK. Adapun variabel tersebut kemudian ditinjau berdasarkan total siswa, yang disajikan dalam bentuk prosentase penilaian terhadap jumlah siswa seluruhnya maupun ditinjau dari prosentase per level variabel. Variabel penilaian tersebut kemudian dianalisa terhadap variabel penilaian

\section{Analisa Hasil Penilaian Siswa Terhadap Sumber Informasi Yang Diperoleh Tentang SMK Bisnis Dan Teknologi}

Dari hasil penelitian diperoleh bahwa siswa memperoleh informasi tentang SMK Bisnis dan Teknologi dari berbagai sumber informasi yang diperolehnya sebagaimana yang ditunjukkan pada Tabel 5.1, yang ditinjau dari 60 siswa yang belajar di SMK Bisnis dan Teknologi, sebagaimana yang tertera di bawah ini.

\section{Sumber Informasi Tentang SMK Bisnis dan Teknologi}

Tabel 5.1. Sumber Informasi SMK Bisnis dan Teknologi Yang Diperoleh Siswa

\begin{tabular}{|l|r|r|}
\hline \multicolumn{3}{|c|}{ Informasi tentang SMK BISTEK } \\
\hline \multicolumn{1}{|c|}{ KETERANGAN } & JUMLAH & $\%$ \\
\hline Spanduk & 10 & 16,7 \\
Brosur & 23 & 38,3 \\
Presentasi & 3 & 5,0 \\
Rekomendasi Teman & 16 & 26,7 \\
Pilihan Orang Tua & 19 & 31,7 \\
Pilihan sendiri & 14 & 23,3 \\
Rekomendasi Guru & 0 & 0,0 \\
Lain-lain & 3 & 5,0 \\
\hline
\end{tabular}

Berdasarkan data yang diperoleh dari hasil penelitian, menunjukkan bahwa sebanyak 60 siswa memperoleh informasi tentang SMK Bisnis dan Teknologi berasal dari Spanduk, Brosur, Presentasi di kelas, Rekomendasi Teman, Pilihan dari Orang Tua Siswa yang bersangkutan, memilih atas keputusan sendiri, Rekomendasi dari Guru Sekolah, dan sumber lain. Berdasarkan data, siswa yang memperoleh informasi tentang SMK Bisnis dan Teknologi berasal dari Spanduk sebesar 10 orang atau sebesar $16,7 \%$. Sumber dari brosur sebanyak 23 orang atau sebesar 38,3\%. Memperoleh informasi dari presentasi pihak SMK Bisnis dan Teknologi di 
kelas siswa yang bersangkutan sebesar 3 orang atau sebesar 5\%. Memperoleh informasi dari rekomendasi teman sebanyak 16 orang atau sebesar 26,7\%. Siswa memperoleh informasi tentang SMK Bisnis dan Teknologi karena pilihan dari orang tua siswa sendiri adalah sebanyak 19 orang atau sebesar $31,7 \%$. Sementara siswa yang memperoleh informasi karena mencari sendiri dan atas keputusan diri sendiri sebanyak 14 orang atau sebesa $23,3 \%$. Di sisi lain, rekomendasi guru atas informasi yang diperoleh siswa tentang SMK Bisnis dan Teknologi adalah sebesar 0\%, atau dapat dikatakan bahwa siswa tidak memperoleh informasi tentang SMK Bisnis dan Teknologi dari guru di sekolahnya sendiri. Dan terakhir adalah siswa memperoleh informasi tentang SMK Bisnis dan Teknologi berasal dari faktor lain selain sumber informasi resmi yang ada, yaitu sebanyak 3 orang atau sebesar $5 \%$.

Jika dibandingkan dari sumber-sumber informasi yang ada tersebut, tercatat bahwa porsi tertinggi adalah Brosur sebesar 38,3\%. Sementara porsi sumber informasi tertinggi berikutnya disusul oleh Pilihan Orang Tua siswa sebesar 31,7\%.

\section{Faktor Keputusan Siswa Mendaftar di SMK Bisnis dan Teknologi}

Ditinjau dari aspek non promosi, ternyata terdapat beberapa faktor yang memengaruhi keputusan siswa untuk mendaftar di SMK Bisnis dan Teknologi sebagaimana yang dicantumkan di Tabel 5.2 berikut:

\section{Tabel 5.2. Faktor-Faktor yang Memengaruhi Keputusan Siswa Mendaftar}

\begin{tabular}{|l|r|c|}
\hline \multicolumn{1}{|c|}{ KETERANGAN } & JUMLAH & $\%$ \\
\hline Jurusan sesuai minat & 45 & 75,0 \\
\hline Program sekolah lengkap & 10 & 16,7 \\
\hline Fasilitas Belajar Lengkap & 9 & 15,0 \\
\hline Gedung Sekolah \& Sarana Fisik bagus & 7 & 11,7 \\
\hline Kompetensi Guru Sesuai Bidang & 17 & 28,3 \\
\hline
\end{tabular}

Berdasarkan data yang diperoleh dari hasil penelitian, menunjukkan bahwa sebanyak 60 siswa responden yang memutuskan untuk mendaftar di SMK Bisnis dan Teknologi, dipengaruhi oleh beberapa faktor utama antara lain SMK Bisnis dan Teknologi menyediakan jurusan yang sesuai dengan minat siswa yang bersangkutan, Program Kegiatan Sekolah yang dinilai lengkap, Fasilitas Belajar yang lengkap, Gedung dan Sarana Fisik Sekolah yang representatif, Kompetensi 
Guru Mata Pelajaran yang sesuai dengan bidangnya. Berdasarkan data, jurusan yang disediakan oleh SMK Bisnis dan Teknologi sesuai dengan minat siswa itu sendiri, yaitu sebanyak 45 orang, atau sebesar 75\%. Program Kegiatan Siswa yang dinilai lengkap sebanyak 10 orang atau sebesar 16,7\%. Fasilitas Belajar yang dinilai lengkap sebanyak 9 orang atau sebesar 15,5\%. Infrastruktur seperti Gedung Sekolah dan Sarana Fiosik yang representatif bagi sisaw dalam proses kegiatan belajar juga memengaruhi siswa sebanyak 7 orang atau sebesar 11,7\%. Dan terakhir yangtak akalah pentingnya adalah kompetensi Guru mata pelajaran yang sesuai dengan bidangnya mampu memengaruhi siswa sebanyak 17 orang atau sebesar $28,3 \%$.

Jika dibandingkan di anatar faktor-faktor yang memengaruhi keputusan siswa unntuk mendaftar di SMK Bisnis dan Teknologi, maka diperoleh bahwa faktor paling besar yang memengaruhi siswa adalah kesesuaian antara minat dengan jurusan yang disediakan oleh pihak SMK Bisnis dan Teknologi. Faktor terbesar kedua adalah sebagian besar yang mendaftar di SMK Bisnis dan Teknologi disebabkan oleh siswa mengetahui kompetensi yang dimiliki oleh Guru Mata Pelajaran di SMK Bisnis dan Teknologi dengan baik.

Analisa Dan Interpretasi Penilaian Siswa Terhadap Kegiatan Promosi SMK Bisnis Dan Teknologi

Penilaian Siswa Terhadap Iklan SMK Bisnis Dan Teknologi

Tabel 5.4. Penilaian Siswa Terhadap Iklan SMK Bisnis dan Teknologi

\begin{tabular}{|c|c|c|c|c|}
\hline \multirow{2}{*}{ Pernyataan } & \multicolumn{4}{|c|}{ PENILAIAN } \\
\cline { 2 - 5 } & YA & $\%$ & TIDAK & $\%$ \\
\hline 1 & 29 & 48,3 & 31 & 51,7 \\
\hline 2 & 37 & 61,7 & 23 & 38,3 \\
\hline 3 & 32 & 53,3 & 28 & 46,7 \\
\hline 4 & 40 & 66,7 & 20 & 33,3 \\
\hline 5 & 50 & 83,3 & 10 & 16,7 \\
\hline 6 & 50 & 83,3 & 9 & 15,0 \\
\hline 7 & 42 & 70,0 & 18 & 30,0 \\
\hline
\end{tabular}

Tabel 5.4. menunjukkan data mengenai siswa yang terpapar iklan dari SMK Bisnis dan Teknologi sehingga mampu memengaruhi mereka untuk mendaftar sebagai siswa. Dari tujuh pernyataan yang ada dalam kuesioner, sebanyak 83,3\% dari 60 
siswa menilai bahwa informasi yang tercantum dalam brosur SMK Bisnis dan Teknologi cukup jelas dan lengkap serta mudah dikenali dengan desainnya yang khas. Sementara jika dibandingkan dengan aktifitas iklan yang dilakukan, nilai terendah sebesar 48,3\% siswa menilai bahwa sering melihat spanduk pengumuman Penerimaan Siswa Baru SMK Bisnis dan Teknologi di setiap sudut jalan yang dilalui.

\section{Penilaian Siswa Terhadap Sales Promotion SMK Bisnis Dan Teknologi}

Tabel 5.5. Penilaian Siswa Terhadap Sales Promotion SMK Bisnis dan Teknologi

\begin{tabular}{|c|r|c|r|c|}
\hline SALES PROMOTION & \multicolumn{4}{|c|}{ PENILAIAN } \\
\hline Pertanyaan & YA & $\%$ & TIDAK & $\%$ \\
\hline 8 & 43 & 71,7 & 17 & 28,3 \\
\hline 9 & 7 & 11,7 & 51 & 85,0 \\
\hline 10 & 53 & 88,3 & 4 & 6,7 \\
\hline
\end{tabular}

Tabel 5.5 menunjukkan penilaian siswa terhadap kegiatan Sales Promotion SMK Bisnis dan Teknologi. Berdasarkan hasil penelitian, respon tertinggi siswa terhadap kegiatan promosi SMK Bisnis dan Teknologi jatuh pada aspek beasiswa yang ditawarkan, yaitu sebesar 53 siswa atau 88,3\%. Penilaian terbesar berikutnya dari siswa adalah pada aspek kegiatan promosi dalam bentuk fasilitas potongan biaya bagi siswa berpestasi, yaitu sebesar 43 siswa atau 71,7\%. Sementara hanya 7 siswa atau 11,7\% yang memanfaatkan promosi SMK Bisnis dan Teknologi dalam bentuk bantuan biaya pendidikan bagi siswa. Dengan kata lain, sebagian besar minat siswa yang tertarik kepada promosi yang dilakukan oleh SMK Bisnis dan Teknologi adalah dalam bentuk potongan biaya bagi siswa berprestasi dan beasiswa.

\section{Penilaian Siswa Terhadap Public Relations SMK Bisnis Dan Teknologi}

Tabel 5.6. Penilaian Siswa Terhadap Public Relations SMK Bisnis dan Teknologi

\begin{tabular}{|c|c|c|c|c|}
\hline PUBLIC RELATIONS & \multicolumn{4}{|c|}{ PENILAIAN } \\
\hline Pertanyaan & YA & $\%$ & TIDAK & $\%$ \\
\hline
\end{tabular}




\begin{tabular}{|r|r|r|r|c|}
\hline 11 & 25 & 41,7 & 34 & 56,7 \\
\hline 12 & 14 & 23,3 & 46 & 76,7 \\
\hline 13 & 47 & 78,3 & 12 & 20,0 \\
\hline 14 & 39 & 65,0 & 19 & 31,7 \\
\hline 15 & 56 & 93,3 & 4 & 6,7 \\
\hline 16 & 54 & 90,0 & 5 & 8,3 \\
\hline
\end{tabular}

Tabel 5.6 menunjukkan kegiatan Public Relations di SMK Bisnis dan Teknologi dalam menarik minta siswa untuk mendaftar. Dari hasil penelitian yang dilakukan, diperoleh data bahwa sebanyak 56 siswa atau 93,3\% menyatakan bahwa pihak SMK Bisnis dan Teknologi selalu memberikan ceramah tentang prospek kerja pada lulusan SMK di masa depan sesuai dengan tuntutan dunia usaha. Artinya, bentuk promosi ini merupakan salah satu cara efektif yang dapat menarik sebagian besar siswa untuk mendaftar di SMK Bisnis dan Teknologi dan sebagian besar siswa tertarik dengan bentuk promosi ini. Di sisi lain, sebanyak 54 siswa atau 90\% menyatakan bahwa salah satu yang menyebabkan siswa mendaftar di SMK Bisnis dan Teknologi adalah karena keputusan orang tua siswa yang mendaftarkan anaknya untuk masuk di SMK Bisnis dan Teknologi. Keputusan tersebut dikarenakan orang tua siswa memiliki kesadaran tentang prospek SMK setelah mengikuti seminar yang dilakukan oleh SMK Bisnis dan Teknologi itu sendiri.

Penilaian Siswa Terhadap Word Of Mouth SMK Bisnis Dan Teknologi

Tabel 5.7. Penilaian Siswa Terhadap Word of Mouth SMK Bisnis dan Teknologi

\begin{tabular}{|r|r|c|r|c|}
\hline WORD OF MOUTH & \multicolumn{4}{|c|}{ PENILAIAN } \\
\hline Pertanyaan & YA & $\%$ & TIDAK & $\%$ \\
\hline 17 & 18 & 30,0 & 42 & 70,0 \\
\hline 18 & 37 & 61,7 & 23 & 38,3 \\
\hline 19 & 2 & 3,3 & 58 & 96,7 \\
\hline
\end{tabular}




\begin{tabular}{|r|r|r|r|r|}
\hline 20 & 20 & 33,3 & 40 & 66,7 \\
\hline 21 & 38 & 63,3 & 22 & 36,7 \\
\hline
\end{tabular}

Word of mouth merupakan salah satu bentuk promosi yang dilakukan oleh pihak SMK Bisnis dan Teknologi dengan cara siswa, orang tua, guru dan pihakpihak lain merekomendasikan SMK Bisnis dan Teknologi kepada orang lain atau calon siswa. Biasanya, rekomendator adalah orang-orang yang mampu memengaruhi orang lain dikarenakan status atau memiliki power tertentu untuk dapat mengajak orang lain mengikuti perintahnya. Dari hasil penelitian yang telah dilakukan, terlihat bahwa sebanyak 38 siswa atau 63,3\% mengatakan bahwa keputusan untuk mendaftar sebagai siswa di SMK Bisnis dan Teknologi atas dasar keinginan sendiri. Sementara, keputusan siswa untuk mendaftar di SMK Bisnis dan Teknologi atas dasar pilihan orang tua adalah 37 siswa atau 61,7\%. Artinya, sebagian besar siswa yang mendaftar di SMK Bisnis dan Teknologi adalah siswa yang memiliki kesadaran sendiri tentang masa depannya. Kesadaran tersebut sebagian besar muncul secara mandiri, dan sebagian lagi karena faktor orang tua yang juga sadar tentang pentingnya karir kerja bagi anaknya di masa depan.

Sementara di sisi lain, faktor dari ajakan teman hanya sebesar 18 orang atau $30 \%$ dari total 60 siswa yang mendaftar. Dan faktor guru adalah yang paling terendah yaitu sebanyak 2 orang atau 3,3\%. Sehingga dari adata tersebut dapat diterjemahkan bahwa tingkat kemandirian keputusan siswa untuk mendaftar di SMK Bisnis dan Teknologi adalah cukup tinggi, di samping juga dengan tingginya kesadaran orang tua siswa terhadap masa depan anaknya untuk diterima di dunia kerja sehingga memutuskan untuk mendaftarkan sang anak ke SMK Bisnis dan Teknologi. Hal ini terlihat dari kecilnya jumlah siswa yang memilih mendaftar di SMK Bisnis dan Teknologi dari faktor ajakan teman dan lingkungan dari siswa itu berada.

\section{Penilaian Siswa Terhadap Event Marketing SMK Bisnis Dan Teknologi}

Tabel 5.8. Penilaian Siswa Terhadap Event Marketing SMK Bisnis dan

Teknologi 
Relasi : Jurnal Ekonomi, Vol. 15, No. 1, Januari 2019, hlm. 69-94

\begin{tabular}{|r|r|c|r|c|}
\hline $\begin{array}{c}\text { EVENT } \\
\text { MARKETING }\end{array}$ & \multicolumn{5}{|c|}{ PENILAIAN } \\
\hline \multicolumn{1}{|c|}{ Pertanyaan } & YA & $\%$ & TIDAK & $\%$ \\
\hline 22 & 55 & 91,7 & 5 & 8,3 \\
\hline 23 & 35 & 58,3 & 25 & 41,7 \\
\hline 24 & 52 & 86,7 & 8 & 13,3 \\
\hline
\end{tabular}

Event marketing merupakan salah satu bentuk promosi dengan cara menyelenggarakan acara-acara tematik yang bertujuan untuk menciptakan eksperiensial bagi konsumen atau target audiens. Dalam hal ini bentuk acara yang dilaksanakan oleh SMK Bisnis dan Teknologi adalah kompetisi dan kontes bagi siswa berprestasi di bidangnya. Acar atersebut bertujuan untuk menciptakan sebuah pengalaman bagi siswa tentang mengasah kemampuan dan keterampilannya dengan komtestan yang lain. Dari situ, siswa akan terlatih dan terasah kemampuan sesuai dibidangnya. Siswa akan mengetahui bahwa dirinya mampu untuk bisa berkompetisi karena memiliki kompetensi yang layak.

Berdasarkan data yang diperoleh dari hasil penelitian terhadap siswa yang mendaftar di SMK Bisnis dan Teknologi, menunjukkan bahwa sebanyak 55 siswa atau 91,7\% menyatakan bahwa SMK Bisnis dan Teknologi selalu menyelenggarakan acara dalam bentuk kompetensi dan kontes bagi siswa yang memiliki kompetensi di bidangnya. Selanjutnya, sebanyak 52 siswa atau 86,7\% mengatakan bahwa acara tersebut sangat bermanfaat bagi siswa yang bersangkutan. Dan sebanyak 35 siswa atau 58,3\% mengikuti acara tersebut dibandingkan siswa yang tidak mengikuti sebesar 25 siswa atau 41,7\% . Artinya, dapat diterjemahkan bahwa kegiatan event marketing yang dilakukan oleh SMK Bisnis dan Teknologi dinilai sangat bermanfaat bagi siswa, dan merupakan salah satu faktor yang mendorong keputusan siswa untuk mendaftar di SMK Bisnis dan Teknologi.

\section{Pembahasan}

Berdasarkan hasil penelitian yang telah dilakukan terhadap siswa di SMK Bisnis dan Teknologi, dapat dijelaskan sebagai berikut.

Dalam hal memperoleh informasi mengenai SMK Bisnis dan Teknologi dari 
siswa yang mendaftar, sebanyak 23 siswa dari 60 responden mengatakan bahwa mereka memperoleh informasi hingga mendaftar di SMK Bisnis dan Teknologi melalui brosur. Sebanyak 19 siswa memperoleh informasi tersebut dari orang tua yang telah menentukan untuk mendaftarkan sang anak ke SMK Bisnis dan Teknologi. Sebanyak 16 siswa memperoleh informasi atas rekomendasi dari teman, sebanyak 14 siswa memperoleh informasi dengan mencari sendiri, sebanyak 10 siswa karena melihat spanduk, dan jumlah terkecil dari siswa yang berhasil memperoleh informasi tentang SMK Bisnis dan Tenologi adalah sebanyak 3 orang melalui paparan presentasi dari pihak SMK Bisnis dan Teknologi di kelas mereka dan sebanyak 3 orang lain memperoleh informasi melalui sumber lain.

Berdasarkan data tersebut, dapat dianalisa bahwa salah satu bentuk media promosi yang paling efektif untuk menyampaikan informasi mengenai SMK Bisnis dan Teknologi adalah brosur. Dan target penyampaian informasi yang paling efektif bagi SMK Bisnis dan Teknologi dalam merekrut siswa baru dan membangun minat siswa untuk mendaftar adalah melalui orang tua siswa yang bersangkutan. Di sisi lain, lingkungan pertemanan dan sosial juga merupakan target yang efektif sebagai sumber informasi yang dapat dipercaya oleh siswa untuk mencari tahu tentang SMK yang diminatinya. Teman merupakan salah satu pihak terdekat yang seringkali dijadikan rujukan oleh siswa dan dipercaya dalam memberikan informasi yang diinginkan siswa tersebut. Keputusan siswa untuk mencari tahu tentang SMK Bisnis dan Teknologi secara mandiri juga merupakan faktor penentu cukup signifikan bagi SMK Bisnis dan Teknologi. Walaupun dari data yang diperoleh atas hasil penelitian menunjukkan jumlah yang tidak signifikan (sebanyak 14 siswa), namun siswa yang lebih memilih untuk mencari tahu sendiri tentang SMK Bisnis dan Teknologi ketimbang sumber informasi mengenai sekolah lain, merupakan target audiens utama dan terpenting bagi SMK Bisnis dan Teknologi. Sementara spanduk, ternyata tidak bisa dijadikan sumber informasi utama karena hanya 10 siswa yang memperoleh informasi tentang SMK Bisnis dan Teknologi. Kondisi tersebut dapat dijelaskan bahwa titik lokasi pemasangan spanduk yang tidak strategis serta desain dan tata letak huruf secara keseluruhan yang melekat pada spanduk tersebut, merupakan salah satu faktor penyebab siswa tidak memperoleh 
informasi secara lengkap mengenai SMK Bisnis dan Teknologi.

Hasil penelitian menunjukkan bahwa terdapat faktor-faktor yang secara garis besatr mempengaruhi keputusan siswa untuk mendaftar di SMK Bisnis dan Teknologi yaitu faktor kesesuaian antara Jurusan yang disediakan oleh SMK Bisnis dan Teknologi dengan minat siswa, kelengkapan program-program pembelajaran yang ada di SMK Bisnis dan Teknologi, kelengkapan fasilitas belajar yang disediakan, tampilan fisik yang representatif dan mendukung siswa untuk belajar seperti gedung sekolah dan sarana fisik seperti laboratorium, perpustakaan dan lainnya, dan terakhir adalah kemampuan yang dimiliki oleh guru mata pelajarana yang sesuai dengan bidang dan latar belakang pendidikannya.

Berdasarkan analisa data yang telah dilakukan, menunjukkan bahwa dari lima faktor besar yang memengaruhi keputusan siswa untuk mendaftar di SMK Bisnis dan Teknologi, sebanyak 45 siswa dari 60 siswa dipengarui oleh kesesuaian antara minat dan jurusan yang disediakan oleh pihak SMK Bisnis dna Teknologi. Faktor terbesar berikutnya adalah kompetensi guru yang sesuai di bidangnya. Berdasarkan data tersebut, dapat dianalisa bahwa SMK Bisnis dan Teknologi telah mampu memenuhi unsur kebutuhan paling utama ketika siswa tersebut memutuskan untuk mendaftar di Sekolah Menengah Kejuruan itu sendiri, yaitu mampu memenuhi minat siswa terhadap kompetensi yang diinginkan, dan mampu memenuhi kebutuhan siswa untuk memperoleh keahlian dan keterampilan dari jurusan yang dipelajarinya.

Dalam konteks iklan dengan menggunakan media brosur dan spanduk yang dilakukan oleh pihak SMK Bisnis dan Teknologi, diperoleh hasil bahwa dari 60 siswa responden, mengatakan brosur dan spanduk sudah informative dan designable. Artinya, pesan promosi yang ingin disampaikan oleh SMK Bisni dan Teknologi melalui kedua media tersebut sudah komunikatif dan mampu dipahami oleh siswa dengan baik.

Kegiatan Sales promotion yang dilakukan oleh SMK Bisnis dan Teknologi juga merupakan salah satu faktor yang memengaruhi keputusan siswa untuk mendaftar. Berdasarkan hasil penelitian, sebagian besar minat siswa untuk mendaftar adalah karena ingin memperoleh beasiswa yang disediakan oleh SMK 
Bisnis dan Teknologi. Hal ini cukup beralasan mengingat setiap kali kegiatan sales promotion dilakukan, SMK Bisnis dan Teknologi selalu "menjanjikan" adanya potongan biaya dalam bentuk beasiswa kepada target siswa. Namun jika diukur dari jumlah siswa yang memperoleh beasiswa, ternyata hanya tujuh orang dari 60 responden yang ditanya. Jumlah ini sangatlah sedikit, dan mengingat pula dampak yang muncul ketika "janji beasiswa" ini dilakukan sangat selektif dalam kategori syarat yang sempit, maka akan melemahkan motivasi siswa yang akan mendaftar di SMK Bisnis an Teknologi. Sehingga perlu bagi pihak SMK Bisnis dan Teknologi untuk merancang kembali bentuk promosi dalam bentuk beasiswa ini dengan kategori yang lebih luas agar cakupan pasar juga bisa lebih luas.

Data hasil penelitian dalam kategori kegiatan public relations yang dilakukan oleh pihak SMK Bisnis dan Teknologi menjelaskan bahwa sebagian besar siswa responden mengatakan bahwa kegiatan public relations yang dilakukan oleh SMK Bisnis dan Teknologi sering dilakukan, namun dari 60 responden, sebanyak 25 orang yang mengatakan bahwa ia hadir dalam kegiatan kegiatan public relations tersebut dan 34 siswa tidak hadir. Sebanyak 14 orang mengatakan bahwa ia pernah diundang dan 46 siswa lainnya mengatakan bahwa ia tidak pernah diundang. Dari 60 responden tersebut, jika ditinjau dari dampak undangan yang dilakukan oleh SMK Bisnis dan Teknologi tersebut terhadap respon siswa pada undangan tersebut, maka dapat dikatakan bahwa kegiatan public relations tersebut efektif. Tanggapan dan respon siswa baik sekali, hal tersebut terlihat dari 14 siswa yang merasa diundang, dan sebanyak 25 (73\%) orang hadir dalam acara tersebut. Namun jika ditinjau dari upaya promosi dalam bentuk mengundang siswa itu sendiri, maka dapat dikatakan lemah. Terbukti dari 60 siswa respnden, hanya 14 (23\%) orang yang mengatakan merasa diundang. Sementara 46 siswa $(76,7 \%)$ tidak merasa diundang. Sehingga dapat dikatakan bahwa cakupan undangan dari SMK Bisnis dan Teknologi tidak optimal. Ditinjau dari sisi kemanfaatan kegiatan public rekations tersebut bagi siswa, dapat dikatakan sudah baik yang terlihat dari sebanyak $47(78,3 \%)$ siswa responden mengatakan acara tersebut sangat bermanfaat bagi mereka. Sehingga dari keseluruhan kegiatan public relaitions yang dilakukan oleh pihak SMK Bisnis dan Teknologi dapat dikatakan bahwa kegiatan 
tersebut mampu membangun minat siswa dan orang tua untuk mendaftar di SMK Bisnis dan Teknologi, ditambah lagi dengan intensitas atau frekuensi kegiatan tersebut yang sering dilakukan. Namun cakupan kegiatan tersebut tidak menjangkau lebih luas dalam jumlah siswa untuk hadir pada acara tersebut. Strategi yang harus dilakukan oleh pihak SMK Bisnis dan Teknologi adalah memperluas cakupan undangan public relations tersebut ke dalam kategori lapisan siswa (misal: kelas 7, 8, 9 SMP). Pihak SMK Bisnis dan Teknologi perlu merancang metode ceramah, materi dan teknik dari kegiatan tersebut secara khusus sesuai dengan karakteristik target audiens di setiap lapisan tersebut. Tujuan secara keseluruhan dari cara ini adalah membangun kesadaran siswa sejak dini tentang dunia uasaha dan karir di bidangnya melalui SMK.

Hasil penelitian dan analisis data mengenai kegiatan promosi dalam bentuk Word of Mouth yang dilakukan oleh pihak SMK Bisnis dan Teknologi menyatakan bahwa sebagian besar siswa memutuskan untuk mendaftar di SMK Bisnis dan Teknologi karena faktor kedadaran diri sendiri. Tentunya hal ini sangat baik bagi SMK Bisnis dan Teknologi karena setiap input siswa yang ikut sebagai peserta didik adalah siswa-siswa yang sudah memiliki konsep dan tujuan diri cukup besar, sehingga pengelolaan peserta didik di sekolah tersebut dapat berjalan dengan baik. Selain itu, kesadaran orang tua terhadap pentingnya menyekolahkan anaknya di SMK juga dapat dikatakan cukup baik. Hal ini terlihat dari 60 siswa responden, sebanyak 37 siswa mengatakan bahwa ia mendaftar di SMK Bisnis dan Teknologi karena faktor pilihan orang tua. Dapat dikatakan bahwa selain tingginya tingkat kesadaran orang tua terhadap pentingnya pendidikan anak, orang tua juga memiliki kesadaran tentang karir dan masa depan anak itu sendiri dalam menghadapi persaingan ketat dalam dunia kerja. Di sisi lain, dari 5 pihak yang menjadi faktor yang memengaruhi keputusan siswa mendaftar, sebanyak 2 siswa mengatakan bahwa mereka mendaftar di SMK Bisnis dan Tenologi karena faktor rekomendasi dari guru di sekolahnya. Tentunya jika dibandingnya dari 4 pihak rekomendator yang lain, peran guru sangat kecil dalam memengruhi keputusan siswa. sehingga strategi yang harus dilakukan oleh pihak SMK Bisnis dan Teknologi adalah harus menjalin kerjasama dan hubungan baik serta memberikan pemahaman tentang 
dinamika dunia kerja kepada guru yang bersangkutan terhadap anak didiknya nanti.

Kegiatan promosi dari aspek event marketing yang dilakukan oleh SMK Bisnis dan Teknologi, diperoleh data bahwa sebagian besar kegiatan yang dilakukan dalam bentuk menyelenggarakan kompetisi dan kontes kompetensi siswa sesuai bidangnya. Kemanfaatan dan dampak dari acara tersebut dinilai baik jika ditinjau dari jumlah siswa yang mengakuinya sebanyak 52 siswa dari 60 responden. Namun keikutsertaan siswa dalam acara tersebut belum optimal, dari 60 siswa responden mengatakan bahwa sebanyak 35 siswa mengikuti dan 25 siswa sisanya tidak ikut dalam acara tersebut. Kondisi ini harus menjadi catatan pertimbangan oleh pihak SMK Bisnis dan Teknologi untuk meningkatkan keterlibatan siswa dalam acara tersebut dan membangun kesadaran siswa akan potensi dirinya melalui kontes dan kompetisi yang ada.

\section{Simpulan}

Berdasarkan hasil penelitian dan pembahasan yang telah dilakukan, maka dalam hal ini dapat disimpulkan sebagai berikut:

1. Secara umum, terdapat 5 hal besar yang perlu dipetakan dalam menentukan strategi promosi di SMK Bisnis dan Teknologi di masa depan, yaitu kesesuaian jurusan yang diminati siswa, ketersediaan program unggulan sekolah, kelengkapan fasilitas belajar, sarana dan pra sarana pembelajaran, kompetensi guru yang sesuai di bidangnya.

2. Dari 5 hal tersebut, terdapat 2 faktor besar yang menjadikan alasan utama bagi siswa untuk mendaftar di SMK Bisnis dan Teknologi, yaitu Bidang Jurusan yang diminati dan Kemampuan guru dalam memberikan materi dan pembelajaran.

3. Dalam kategori media iklan yaitu brosur dan spanduk yang dimiliki SMK Bisnis dan Teknologi, dapat dikatakan sudah komunikatif dan informatif yang terbukti dari pengakuan siswa yang mudah mengenali ciri khas media iklan dai SMK tersebut

4. Poin utama yang menjadi daya tarik siswa untuk mendaftar dalam kegiatan sales promotions yang dilakukan oleh SMK Bisnis dan Teknologi adalah fasilitas beasiswa 
5. Dalam kegiatan public relations, kemanfaatan yang diperoleh siswa sangat tinggi. Serta intensitas kegiatan yang dilakukan tinggi. Namun cakupan dari kegiatan tersebut terhadap jumlah siswa dan lapisan siswa belum optimal

6. Dalam hal bentuk promosi melalui word of mouth, sebagian besar siswa mengatakan bahwa mereka mendaftar atas kesadaran diri sendiri. Sementara rekomendator terbesar berikutnya adalah orang tua. Dalam hal ini, peran guru sebagai rekomendator sangat kecil

7. Dalam kegiatan event marketing, sebagian besar siswa mengatakan bahwa SMK Bisnis dan Teknologi selalu menyelenggarakan acara tersebut dalam bentuk kontes dan kompetisi. Namun jumlah peserta yang mengikuti kegiatan tersebut tidak optimal.

\section{Saran}

Berdasarkan uraian dari kesimpulan di atas, maka saran yang dapat diberikan oleh peneliti adalah sebagai berikut:

1. Pihak manajemen SMK Bisnis dan Teknologi perlu melakukan pemetaan situasi dan kondisi target promosi yang akan dilakukan dan menentukan jenis atau tipikal promosi yang relevan agar dapat fokus kepada kegiatan tersebut untuk mengoptimalkan jumlah siswa yang mendaftar

2. Pihak manajemen SMK Bisnis dan Teknologi harus mengetahui potensi apa yang dimilikinya secara internal dan mampu memprediksi potensi situasi eksternal di masa depan sehingga dapat mengambil langkah-langkah kebijakan promosi yang relevan dan memberikan dapak signifikan

3. Dalam kegiatan public relations di masa depan, SMK Bisnis dan Teknologi perlu meningkatkan cakupan promosi lebih luas dari setiap lapisan target siswa yang ada.d engan begitu, pihak manajemen SMK Bisnis dan Teknologi harus menentukan metode yang relevan dari setiap karaiteristik target siswa tersebut. tujuannya adalah menanamkan kesadaran sejak dini kepada siswa untuk mau mendafgar di SMK Bisnis dan Teknologi

4. Pihak manajemen SMK Binis dan Teknologi perlu membina hubungan dan kerjasa lebih intensif kepada semua pihak yang berperan sebagai 
rekomendator siswa untuk mendaftar. Terutama guru pengajar dari calon siswa yang ada. Peran guru tidak bisa diabaikan dalam hal ini karena mereka sebagai narasumber siswa dalam memperoleh informasi yang kredibel tentang SMK Bisnis dan Teknologi.

\section{DAFTAR PUSTAKA}

Garvin, D.A. (1988), Managing Quality, New York: The Free Press

Indonesia, P. R. (2003). Undang-Undang Republik Indonesia Nomor 20 Tentang Sistem Pendidikan Nasional. Presiden Republik Indonesia. Jakarta: Sekretaris Negara Republik Indonesia.

Kamayuda, D. M. (2016). PERENCANAAN STRATEGI BERSAING SEKOLAH DALAM MENINGKATKAN JUMLAH PESERTA DIDIK BARU DI SALAH SATU SEKOLAH SWASTA SALATIGA. Kelola Jurnal Manajemen Pendidikan, 3 No.1, 15-29.

Nurmayatin, S., \& Sutarmin, S. (2016, September). Perumusan Strategi Guna Peningkatan Daya Saing Sekolah Menengah Kejuruan Ma'arif NU 02 Bumiayu. Jurnal Bisnis dan Manajemen (JBIMA), 4, 202-221.

Rangkuti, F. (2009). Strategi Promosi Yang Kreatif Dan Analisis Kasus Integrated Marketing Communication. Jakarta: PT Gramedia Pustaka Utama.

Tjiptono, Fandy \& Gregorius Chandra (2011),Service, Quality \& Satisfaction, edisi 3, Penerbit ANDY Jogjakarta, Indonesi 